\title{
Evaluation of Personal Hygiene Among Students with Visual Impairment at Al-Nour School for Blind: Ismailia City
}

\author{
AMANY A. ALI FARES, M.Sc.*; MONA S. SHENOUDA, D.N.Sc.* and MERVAT E.E. EL-SHELIL, D.N.Sc.** \\ The Departments of Community Health Nursing*, Faculty of Nursing, Cairo University and \\ Family \& Community Health Nursing**, Faculty of Nursing, Suez Canal University, Egypt
}

\begin{abstract}
Background: Vision impairment and blindness are significant community problem. It has lifelong implication for both the children and their families which affect their self-care skills.

Aim of Study: Evaluation of personal hygiene among Students with visual impairment at El-Nour School for Blind: Ismailia City. Sample: 86 students, 60 of family caregivers.

Subjects and Methods: Descriptive study design was used for conducting this study. Methods: Data were collected by the investigator using three tools. First: Interviewing questionnaire to assess the students' knowledge about personal hygiene. Second: Observational checklist to assess student's practice of personal hygiene. Third tool: A structured interviewing questionnaire for caregivers to assess their knowledge regarding personal hygiene for their children.
\end{abstract}

Result: $79.1 \%$ and $77,9 \%$ of studied students had unsatisfactory knowledge and practices of personal hygiene respectively. $71.67 \%$ of caregivers had satisfactory knowledge of personal hygiene for their children except the oral hygiene.

Conclusion: The students with visual impairment had unsatisfactory knowledge and practices regarding personal hygiene, and the caregivers had unsatisfactory knowledge about oral hygiene for their children.

Recommendation: Support the actual need for implanting a well-planned and continuous intervention program aiming at improving caregivers' knowledge about personal hygiene and follow up with subsequent children practice to detect the achievement.

Key Words: Visual Impairment - Personal Hygiene - Caregiver - Nursing Role.

\section{Introduction}

VISION impairment and blindness are critical group issue. It influences 285 million individuals are assessed to be outwardly weakened around the world: 39 million are visually impaired and 246 have low vision [1].

Correspondence to: Dr. Amany A. Ali Fares, E-Mail: amanyfares911@yahoo.com
Visual impairment in childhood has a lifelong implication for both the child and their family. It affects the child development, education, and caregivers by families. The person with visual impairment cannot see anything forever and depend on others to cope with their life [2]

Hygiene is the science of health and maintenance. It is highly personal determined by individual values and practices power. Hygiene and good habits are commonly understood as a prevention method against infection and illness. This means not only washing hands but also bathing, washing hair, brushing etc. maintaining good personal hygiene helps to fight against infection by removing essence that allow bacteria to grow from the surface of the skin [3].

Caregivers of children with visual impairment (including biological parents, grandparents and residential caregivers) play a significant role in the development of independence in children with visual impairments during pre-school years [4]. It was also found that they usually respond effectively to the amount of support the children need [5]

The community health nurse may care for children who have disabilities, they may also support students with vision impairment to live and work in community, the role of the nurse to enable each student to choose the life which he/she wishes and to enables to attain it. So the community health nurses must have a different skill that equipped them to offer support and communicate empathically in meaningful life with each visually impaired student. Also, cooperates with their teacher and their families which help in prevention of social, physical, and psychological problem to those children as early as possible [6] 
Vision is a vital mean of obtaining information fromthe environment, lack of sight can severely limit aperson's experience. And influence on gainingactual knowledge of objection world, which can then be had bytouch experience [7]. Vision is important for achievement of independence in children 13-15 year to be independent living skills. The loss of vision due to any causes major changes in lifestyle, and habits [8].

Maintaining personal hygiene is crucial for everyone it may affect all aspects e.g. personal social interaction, psychological lives. Keeping a good standard of hygiene helps to prevent bad odors and spread of infections consequently the development of illness. Because visual impairment effect on social interaction, the blind students may experience difficulties with attachment resulting from failure of eye contact and facial expressiveness. For instance, smiling is not recognized or imitated by blind child or adolescent [9] .

\section{Patients and Methods}

\section{1- Research design:}

Descriptive study design was used for conducting the study.

\section{Setting:}

The study was conducted at El-Nour SchoolIsmailia City. The only school in Ismailia city. It is boarding governmental school for male and female students with visual impairment. It consists of two buildings each one contain two floors. Data were collected within 3 months period started from the 2 of October 2015 to end of December 2015.

\section{Sample:}

They were 86 students 51 students in primary education, 13 students in preparatory education and 22 students in secondary education. And 60 of family caregivers responsible for care their children.

\section{Tools of Data Collection:}

Three tools were used prepared by the investigator after review of related literature and tested by a panel of experts for validity as the following:

\section{Tool (1):}

Interviewing questionnaire for students; Developed by the investigator based on literature review it consists of two parts:

\section{Part 1:}

- Personal characteristic for students e.g. age, sex, grade, residence ..... etc.,
- Causes of Visual impairment.

- Source of knowledge about personal hygiene etc.

\section{Part 2:}

This part covered the area of knowledge and practice of personal hygiene e.g.(hand washing, cutting nails, hair clean etc.

Tool (2):

- It developed by the investigator based on literature review.

- An observational checklist to assess students practices regarding personal hygiene e.g. (hand washing, nail cut, and tooth brushing.

Tool (3):

- A structured interviewing questionnaire for family caregivers.

- Knowledge regarding personal hygiene for their children such as (oral hygiene, hand washing .......... etc.

- Administrative design: Formal letters issued from the Faculty of Nursing, Suez Canal University to obtain an official approval to carry out the study at El-Nour school for blind in Ismailia city. The letters explain the aim of study, clarifies its procedure and tool which used for data collection. The permission was obtained before initiation of the study.

\section{2- Data collection procedure:}

The investigator interviewed each student (male and female) and their families individually at ElNour School for Blind in Ismailia City, the purpose of the study was explained to each student and caregiver to gain their consents and cooperation before participation, they were informed about their rights to withdraw from the study at any time and the data collected from them will be just for research and kept confidentially, and will be used just for the purpose of the study.

Data were collected within 3 months period started from the 2 of October 2015 to end of December 2015. Data was collected 2 days/ week on Sunday and Monday from 9am to $1 \mathrm{pm}$ during break and absent of teacher. The researcher interviewed, ask each students and caregiver individually; the approximate time spent with each student and caregiver during the interview to complete the sheet was 30 to 45 minutes depending on the response of interviewee.

\section{3- Scoring system:}

Data collected through questionnaire were coded and computed. Statistical analysis was performed 
used the statistical SPSS program. For the knowledge, practical knowledge and practice items, the response were scored (1) and (0) for the incorrect answer and don't know. For each part the scores of items were summed up and converted into a percentage. The scores were converted to qualitative variable through categorization based on cut off $60 \%$. The students' knowledge and practices were considered unsatisfactory if percent scores were less $60 \%$ and satisfactory if $60 \%$ or more.

\section{Ethical considerations:}

All ethical considerations were considered for privacy and confidentiality, so approval was obtained from El-Nour school for blind in Ismailia city before conducting the study, ensuring students and their family caregiver's that these data will be used for research purpose only.

\section{Results}

These results: Shows that $53.5 \%$ of studied students were males. The mean age of studied students were $11.7 \pm 3.3$ years. Result revealed that $59.3 \%$ of studied students were at primary level. While $72.1 \%$ of studied students were living in rural area. While $40.7 \%$ of studied students were the first child in their family. Results also show that, $68.6 \%$ of studied students had visual impairment due to congenital causes.

The result shows that, $32.6 \%$ of studied students' mothers were cannot read and write, while $14.0 \%$ had university education. Results revealed that $36.0 \%$ of studied students' fathers were cannot read and write and $10,5 \%$ had university education.

The results illustrate that; $93 \%$ of studied students get their information about personal hygiene from their parents followed by school $58.1 \%$, while only $3.5 \%$ was their friends.

Table (1): shows that, there were statistical significant differences between studied students' knowledge and their age and educational levels $(p=0.004)$.

Table (1): Difference between studied students' knowledge about personal hygiene and their personal characteristics and parent educational levels $(n=86)$.

\begin{tabular}{|c|c|c|c|c|c|}
\hline \multirow{3}{*}{$\begin{array}{l}\text { Socio-demographic } \\
\text { characteristics }\end{array}$} & \multicolumn{4}{|c|}{ Knowledge score of studied students } & \multirow{3}{*}{ Significance } \\
\hline & \multicolumn{2}{|c|}{$\begin{array}{l}\text { Unsatisfactory } \\
(<60 \%)(\mathrm{n}=45)\end{array}$} & \multicolumn{2}{|c|}{$\begin{array}{l}\text { Satisfactory } \\
(60 \% \leq)(n=41)\end{array}$} & \\
\hline & No. & $\%$ & No. & $\%$ & \\
\hline \multicolumn{6}{|c|}{$\begin{array}{l}\text { Socio-demographic characteristics } \\
\text { of studied students: }\end{array}$} \\
\hline $\begin{array}{l}\text { Gender: } \\
\text { Male } \\
\text { Female }\end{array}$ & $\begin{array}{l}25 \\
20\end{array}$ & $\begin{array}{l}55.6 \\
44.4\end{array}$ & $\begin{array}{l}21 \\
20\end{array}$ & $\begin{array}{l}51.2 \\
48.8\end{array}$ & $\begin{array}{l}\mathrm{X}^{2}=0.162 \\
p=0.687\end{array}$ \\
\hline $\begin{array}{l}\text { Age: } \\
\text { 6-12 years } \\
13-<15 \text { years } \\
15-<18 \text { years }\end{array}$ & $\begin{array}{l}33 \\
7 \\
5\end{array}$ & $\begin{array}{l}73.3 \\
15.6 \\
11.1\end{array}$ & $\begin{array}{l}18 \\
6 \\
17\end{array}$ & $\begin{array}{l}43.9 \\
14.6 \\
41.5\end{array}$ & $\begin{array}{l}\mathrm{X}^{2}=10.870 \\
p=0.004^{*}\end{array}$ \\
\hline $\begin{array}{l}\text { Educational level: } \\
\text { Primary } \\
\text { Preparatory } \\
\text { Secondary school }\end{array}$ & $\begin{array}{l}33 \\
7 \\
5\end{array}$ & $\begin{array}{l}73.3 \\
15.6 \\
11.1\end{array}$ & $\begin{array}{l}18 \\
6 \\
17\end{array}$ & $\begin{array}{l}43.9 \\
14.6 \\
41.5\end{array}$ & $\begin{array}{l}\mathrm{X}^{2}=10.872 \\
p=0.004^{*}\end{array}$ \\
\hline $\begin{array}{l}\text { Residence: } \\
\text { Rural } \\
\text { Urban }\end{array}$ & $\begin{array}{l}34 \\
11\end{array}$ & $\begin{array}{l}75.6 \\
24.4\end{array}$ & $\begin{array}{l}28 \\
13\end{array}$ & $\begin{array}{l}68.3 \\
31.7\end{array}$ & $\begin{array}{l}\mathrm{X}^{2}=0.562 \\
p=0.453\end{array}$ \\
\hline $\begin{array}{l}\text { Cause of visual impc } \\
\text { Congenital } \\
\text { Acquired }\end{array}$ & $\begin{array}{l}31 \\
14\end{array}$ & $\begin{array}{l}68.9 \\
31.1\end{array}$ & $\begin{array}{l}28 \\
13\end{array}$ & $\begin{array}{l}68.3 \\
31.7\end{array}$ & $\begin{array}{l}\mathrm{X}^{2}=0.001 \\
p=0.953\end{array}$ \\
\hline Parents educational & & & & & \\
\hline $\begin{array}{l}\text { Educational level of } \\
\text { Illiterate } \\
\text { Basic education } \\
\text { Secondary } \\
\text { University }\end{array}$ & $\begin{array}{l}13 \\
15 \\
11 \\
6\end{array}$ & $\begin{array}{l}28.9 \\
33.3 \\
24.5 \\
13.3\end{array}$ & $\begin{array}{l}15 \\
10 \\
10 \\
6\end{array}$ & $\begin{array}{l}36.6 \\
24.4 \\
24.4 \\
14.6\end{array}$ & $\begin{array}{l}\mathrm{X}^{2}=1.01 \\
p=0.799\end{array}$ \\
\hline $\begin{array}{l}\text { Educational level of } \\
\text { Illiterate } \\
\text { Basic education } \\
\text { Secondary } \\
\text { University }\end{array}$ & $\begin{array}{l}18 \\
13 \\
10 \\
4\end{array}$ & $\begin{array}{l}40.0 \\
28.9 \\
22.2 \\
8.9\end{array}$ & $\begin{array}{l}13 \\
11 \\
12 \\
5\end{array}$ & $\begin{array}{l}31.7 \\
26.8 \\
29.3 \\
12.2\end{array}$ & $\begin{array}{l}\mathrm{X}^{2}=1.08 \\
p=0.781\end{array}$ \\
\hline
\end{tabular}


Table (2): Shows that, there were statistical significant differences between studied students' practical knowledge and their causes of visual impairments and their parents educational levels $(p=0.004, p=0.01)$

Table (3): Shows that, there were statistical significant differences between studied students' observational practices of personal hygiene and their educational levels and causes of visual impairment and their father educational level ( $p=$ $0.005)$.

Table (4): Shows that, $41.6 \%$ of studied caregivers were in age group 25 to less than 35 years old, $68.3 \%$ of studied caregivers were female. Only $35 \%$ of studied caregivers had secondary school education, $50 \%$ of care givers lived in families consisted of four persons, $51.7 \%$ of caregivers were mothers and $66.7 \%$ of families were extended family.

Fig. (1): Show that, the studied students had unsatisfactory regarding personal hygiene items except cutting nails, bathing, and hygiene during menstruation.

Fig. (2): Show that; the studied students had unsatisfactory regarding tooth brushing, hand washing, and cutting fingernails practices.

Fig. (3): Show that; the studied family caregivers had satisfactory knowledge regarding personal hygiene for their children.

Table (2): Differences between studied students' practical knowledge about personal hygiene and their personal characteristics and parents educational levels.

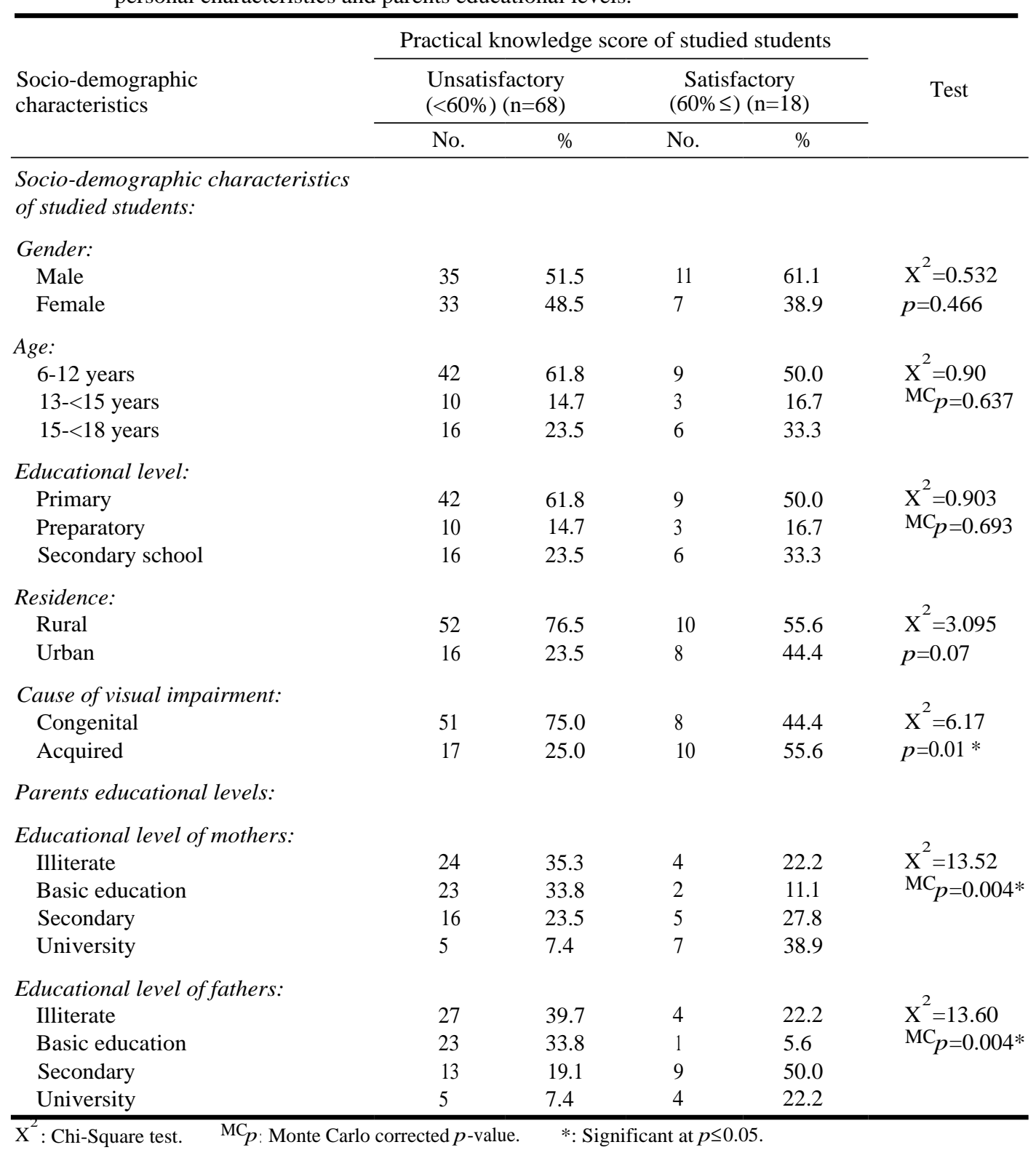


Table (3): Differences between studied students' observational practices of personal hygiene and their personal characteristics and parent educational levels.

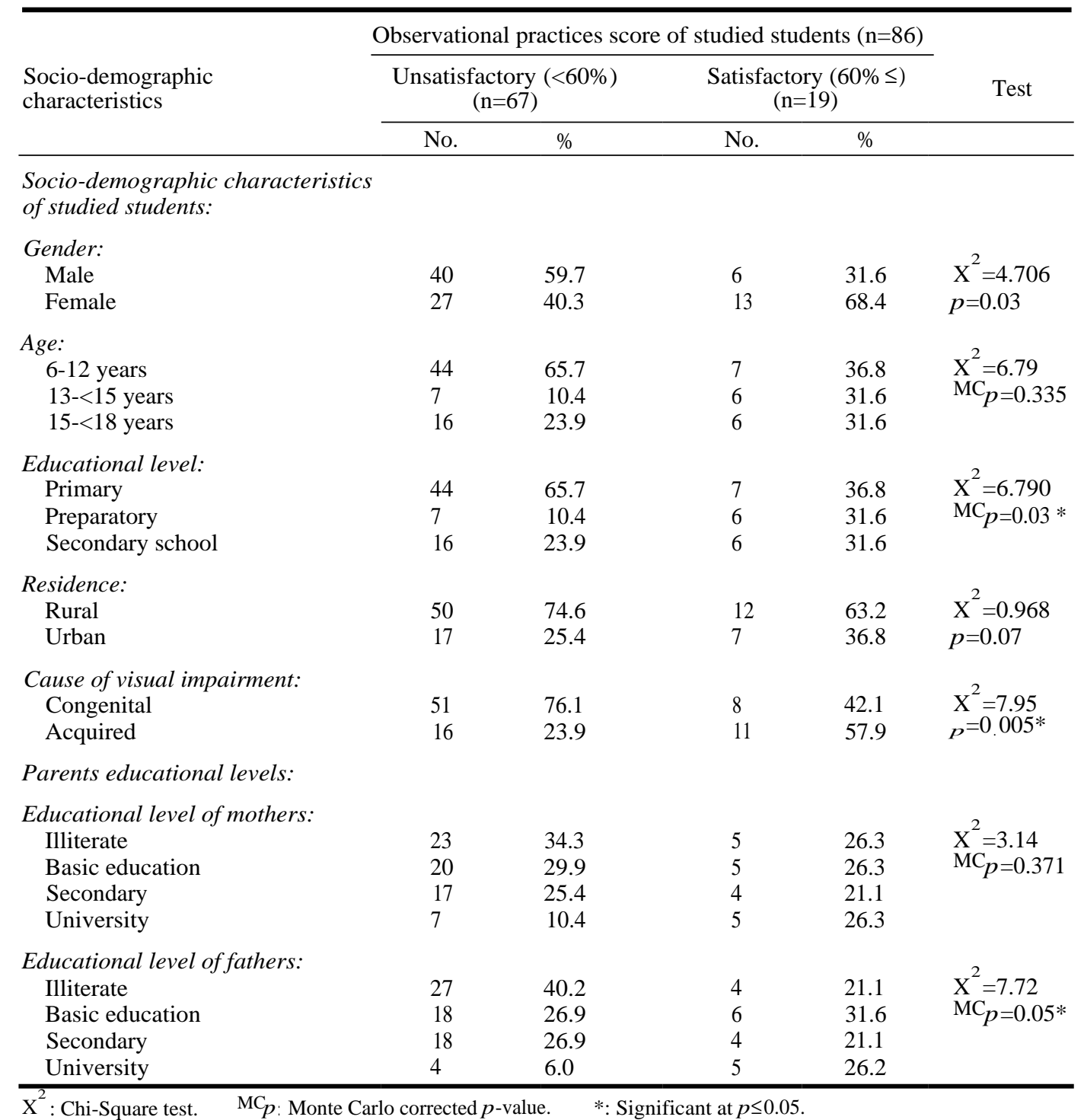

Table (4): Distribution of studied students' family caregiver Table (4): Count.

\begin{tabular}{|c|c|c|c|c|c|}
\hline \multicolumn{3}{|c|}{ according to their family characteristics. } & \\
\hline \multirow{2}{*}{ Personal characteristics } & \multirow{2}{*}{ Number } & \multirow{2}{*}{ Percentage } & Personal characteristics & Number & Percentage \\
\hline & & & Number of family members: & & \\
\hline Age: & & & 4 persons & 30 & 50.0 \\
\hline $25-$ & 25 & 41.6 & & & \\
\hline $35-$ & 20 & 33.3 & 5 persons & 20 & 33.3 \\
\hline $40-45$ years & 15 & 25.1 & 6 persons & 10 & 16.7 \\
\hline Sex: & & & Relation to child: & & \\
\hline Male & 19 & 31.7 & Father & 20 & 33.3 \\
\hline Female & 41 & 68.3 & Mother & 31 & 51.7 \\
\hline Educational level: & & & Brother & 4 & 6.7 \\
\hline Illiterate & 12 & 20.0 & Sister & 5 & 8.3 \\
\hline Primary level & 8 & 13.3 & & & \\
\hline Preparatory level & 12 & 20.0 & Type of family: & & \\
\hline Secondary school level & 21 & 35.0 & Nuclear family & 20 & 33.3 \\
\hline University graduate & 7 & 11.7 & Extended family & 40 & 66.7 \\
\hline
\end{tabular}




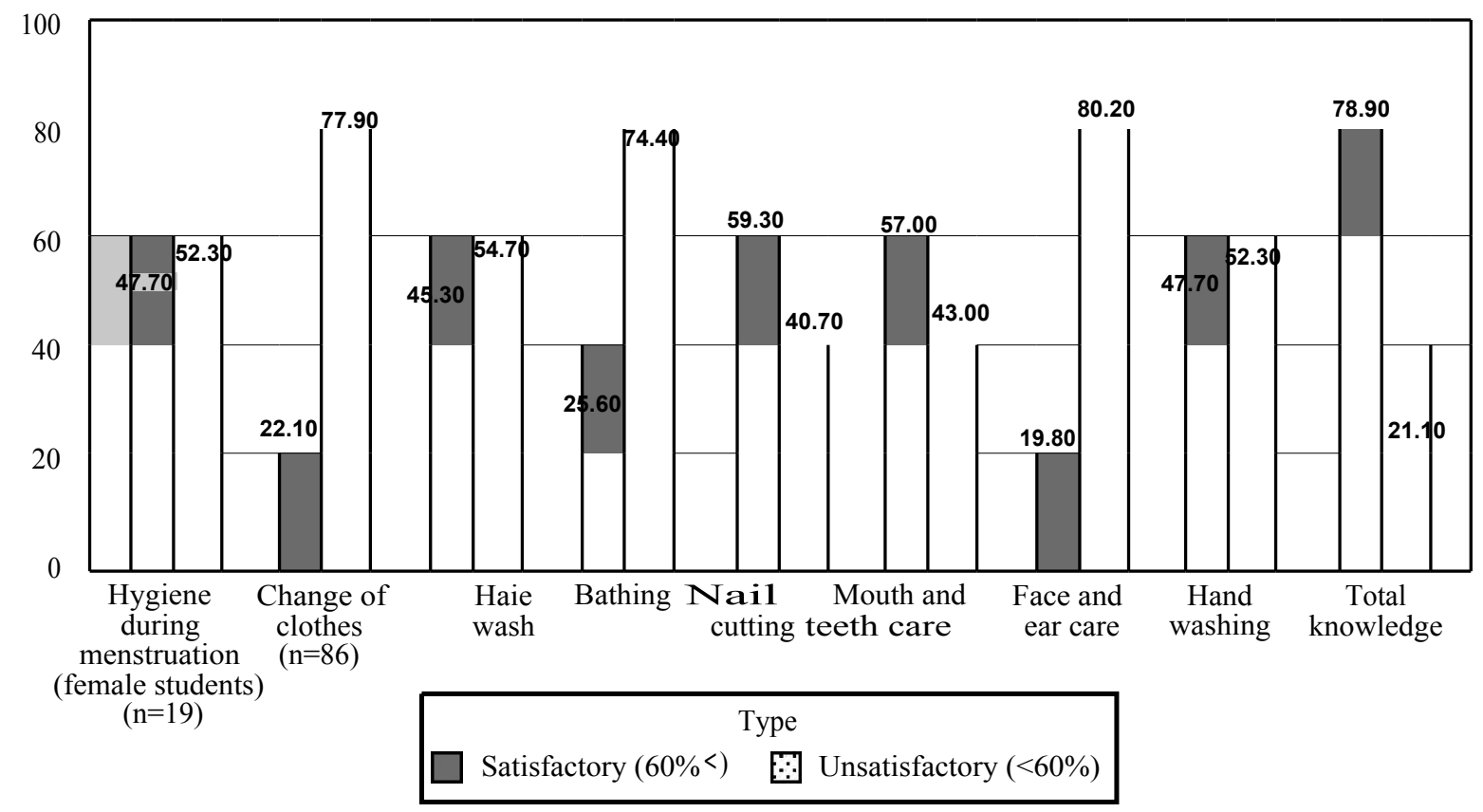

Fig. (1): Distribution of studied students according to their Knowledge about personal hygiene.

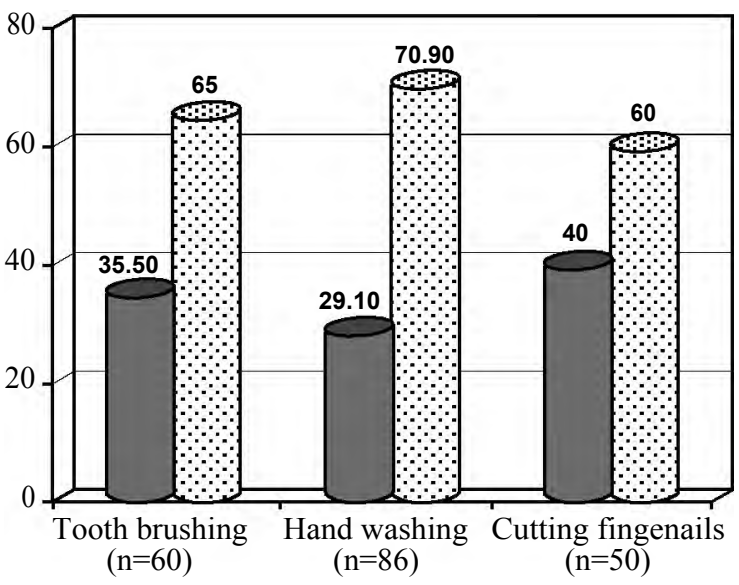

Satisfactory $(60 \%<) \quad \therefore$ Unsatisfactory $(<60 \%)$

Fig. (2): Distribution of studied students according to observational checklist of tooth brushing, hand washing and cutting fingernails.

\section{Discussion}

The results of the present study revealed that; more than half of study students were males, the age of students ranged between 6-12 years were at primary school. From the investigator point of view, this may be related to the family need to train their children reading and writing, independence in daily living activities, while the less percentage of secondary school related fear of social stigma or directed to work.

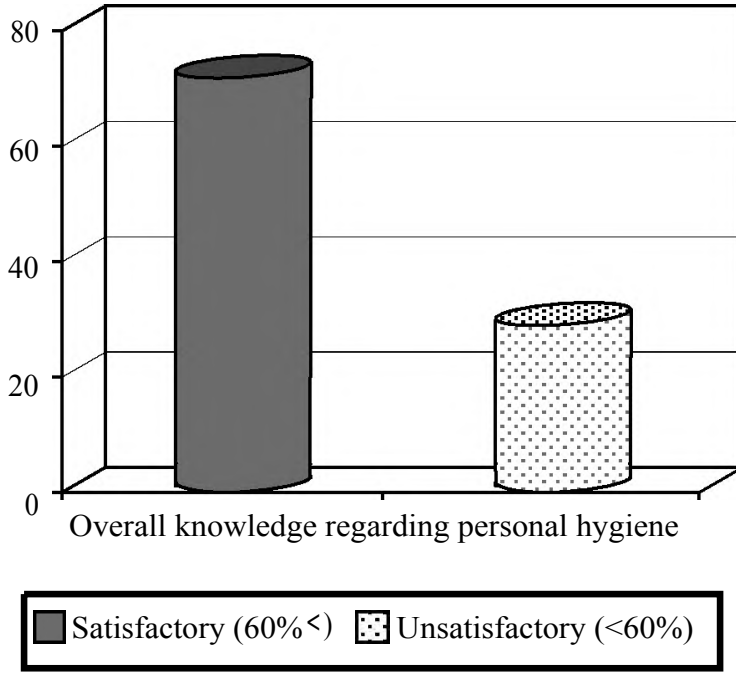

Fig. (3): Distribution of studied family caregivers according to their overall satisfactory knowledge about personal hygiene for their children.

The current study, more than half of students were male, while the rest of them were female These findings were supported by [10], who found that, $60.0 \%$ of children were boys and $40.0 \%$ of them were girls. From the investigator point of view, this could be related to the traditional which impose that visually impaired girls should stay at home for fear of sexual assault or for social stigma, and doesn't send to school. Otherwise, visually impaired boys could be sent to the school where they trained for certain education or occupation. 
Concerning studied students residence the finding of the current study revealed that; three quarters of study students' lives in rural areas. This result was supported by [6] who stated that; the percentage of people with who are blind is higher in rural areas than urban areas. From the investigator point of view, this could probably be due to the differences between rural and urban areas in socioeconomic conditions, health care practices, and access to vision care.

The current study revealed that; nearly one quarter of study students were the first child in their family. Based on the [11], classification of the causes of childhood blindness (the visual loss in infants can be either prenatal (i.e., occurring at the time of conception or during the intrauterine period) or postnatal (during or after birth)), this finding may be the result of genetic factors or environmental factors of the pregnant mother (such as, drugs, accidents, infections, infections, etc.) That; lead to the child being born in totally or partially blind, which the family tries to avoid those cases with the second and third pregnancy

Regarding causes of visual impairment; in the present study the most common cause for visually impairment was congenital causes. This finding was in the same line with [12]; in England, that the majority of the study sample of vision impairment was related to hereditary cause. $38 \%$ due to disease on the eye and $19 \%$ of cases was due to nystagmus. Also, in the study of [13] ; in Zulfi, the most important causes for vision impairment was related to retinal separation. This finding could be related to increase number of relative marriage, where most of the studied sample of parents were relatives and indicate the need for premarital counselling [14] Who studied changing the way we think about blindness myth and reality in London, the researcher note that acquired vision impairment are the most common cause which makes the skills needed for child development and social support may be lower than for the congenitally blind population.

The present study showed that; one third of studied student's mothers were cannot write and read, while small percentage had university education. While more than one third of studied student's fathers were cannot write and read, while small percentage had university education. These results in line with [15], who revealed that; highest prevalence of parents of child blindness were found among low educational and only fifth of them completed their university education due to low socio-economic standards of their families.
The current study revealed that parents were reported as the most common source of knowledge about personal hygiene among the studied students with visual impairment while their friends were the least. This study is in line with studies which stated that, for the blind; the family is the center of the main support in learning and gaining confidence. Family gives the greatest support to the blind especially in the area of proper personal hygiene practice [16].

Concerning to the observed practices of personal hygiene in areas of tooth brushing, hand washing and cutting fingernails among the studied students, the current study shows there are the practices were unsatisfactory. The results of this study is in line with other studies which reported that; oral hygiene knowledge and practices among schoolchildren is poor and needs to be improved [17] and was consistent with studies [18] who found that; the majority the studied sample had unsatisfactory practice regarding hand hygiene in his research.

From the investigator point of view accordance to the results obtained from this study concerning the unsatisfactory level of knowledge of caregivers regarding oral hygiene meaning that this is reflected to and thus resulted in this unsatisfactory practice level among the studied participants.

Regarding cutting fingernails, the findings disagreement with [19] who revealed that; that; the thee quarter of blind female were performed nails care by here self at El-Nour and Al-Amal School for Blind in Cairo [20] who mentioned that; selfdiscovery and practice are the keys to mastery of skills-not step-by-step guides convinced Gilmer that; the same principle applies to blind children.

This result could be attributed to many daily living activities and personal hygiene skills (tooth brushing, hand washing and cutting fingernails) are learned by watching other people. Because the opportunity for incidental visual learning is reduced or non-existent, a blind or visually impaired child often needs special attention for this activities and skills [21]

The present study showed that; there were statistical significant difference between studied students' knowledge and their age and educational levels $(p<0.05)$. This result is contrary with [22] who reported that; there was no significant relationship between visually impaired children knowledge of different aspects of personal hygiene with selected demographic variables like age and children education. 
While there were a statistical significant difference between studied students' practical knowledge and their parents educational levels. According to [23] it is a well-known fact that; one's level of education has an impact on both perceptions and behaviors. Where, parents with high education can obtain information about how deal with children with physical disability and understand about skill needed in daily living activities better than less education.

The present study revealed that; a statistically significant positive correlations between their total knowledge scores of the students and their total practice scores and correlation between total knowledge score and Observational score, also statistically significant was found between students total practice score and their observational score.

These result in line with [24] done at El-Nor and El-Aml Institute in Cairo found statistically significant relations between total knowledge score regarding personal hygiene.

In the current study revealed that; more than half of studied caregivers were mothers, two third them lived in extended family. From the researcher point of view; the mother is the only one who sacrifices her health and gives all her time and effort for her children. Most of studied students and their caregiver were living in rural area which characterized by extended families.

These results is in line with [25], who revealed that highest prevalence of parents of female blindness were found among low educational and only fifth of them completed their university education due to low socio-economic standards of their families.

Results of this study revealed that; most of the studied caregivers with satisfactory level of overall knowledge were in the age group 25>35 years. This is followed by age group from $40>45$.

There was no statistically significant difference between caregivers overall knowledge and their gender, educational level, number of family members and types of family. While there were statistically significant difference between caregivers age and their relation to children. This is supported by [26] who found no significant difference regarding attitude and knowledge between male and female parents scores. This is also supported by results obtained by [6], who reported that; was significant negative correlation between age and knowledge implying that; younger participants have greater hygiene knowledge.

\section{Limitation of the study:}

1- The investigator did not notice all the students during the practice of some personal hygiene due to the refusal of some students and the lack of time sometimes.

2- The investigator did not cover all the family caregivers of the children because this sample unavailable.

\section{Conclusion:}

Based on the findings of the current study, it is concluded that:

- Most of studied students had satisfactory practical knowledge about nail trimming, bathing, and hygiene during menstruation while they had unsatisfactory practical knowledge regarding hand washing, face and ear care, oral and dental hygiene, hair washing, and changing of clothes.

- Most of studied students had unsatisfactory practice regarding tooth brushing, hand washing and cutting fingernails respectively.

- There were statistical significant difference between studied students' knowledge, practical knowledge, and observational practice regarding personal hygiene and their age and educational levels, causes of visual impairments and their parents' educational levels.

- Most of caregivers had satisfactory knowledge regarding all items of personal hygiene for their children except the area of mouth and teeth care.

- There were statistically significant differences between caregiver's knowledge of personal hygiene and their age and relation to child.

\section{Recommendations:}

In the light of the discoveries of current review the accompanying proposals were recommended:

- Continuous assessment of the level of knowledge and practice regarding personnel hygiene among visually impaired students and their caregivers to identify their needs and problems.

- School based health education programs should be undertaken to improve blind students' knowledge and practices with regard to personal hygiene among them.

- Teach students with visual impairment about oral hygiene matters. Demonstration using aids like full mouth model and toothbrush greatly, they can sense of touch to tell them what vision to tell others to develop personal skills.

- Support the actual need for implanting a wellplanned and continuous intervention program 
aiming at improving caregivers' knowledge about personal hygiene and follow-up with subsequent children practice to detect the achievement.

\section{References}

1- WHO: Visual impairment and blindness, Retrieved from: http: //www.who. int/mediacentre/factsheets/fs2 82/en/, 2014.

2- WHO: World Health Organization International Statistical Classification of Diseases and Related Health Problems: 10th revision Current version for Chapter VII H54 Blindness and Low Vision. htp://www. who.int/classi fications/icd/en/, 2014.

3- RESMI: Knowledge of Visually Challenge Children Regarding Personal Hygiene. Department of Community Health Nursing; International Journal Of Multidisciplinary Research Review, Vol. 1, Page, 258-260, 2016.

4- HEATON M.M. and FALOLA T.: HIV/AIDS, Illness, and African Well-being. University Rochester Press, p., 126. www.jstor.org/stable, 2007.

5- GRANT ARTHUR C. and THIAGARAJA MAHESH C. "Tactile Perception in Blind Braille Readers". Psychological Abstracts, 89 (5). https://pdfs.semanticscholar.org , 2010.

6- FLANGAN N., JACKSON A. and HILL A.: Visual impairment in childhood: Insights from a community-based survey. Child care health dev. Vol., 29 (6): pp. 493-499, 2010.

7- CAMPBELL J.: Maternal directives to young children who are blind. Journal of Visual Impairment and Blindness, 97 (6): 355-365, 2009.

8- VALE D. and SYMTH C.: Changing the way we think about blindness: Myth and reality. London., Vol. 13 (8): $1415,2002$.

9- LANGOYA C.O. and FULLER N.J.: Assessment of knowledge of hand washing among health care providers in Juba Teaching Hospital, South Sudan. Midwives, 16: 7-8. www.ijic.info/article, 2015.

10- RAHI J., MANARAS I., TUOMAINEN H. and HUNDT G.: Health Services experience of parents of recently diagnosed visually impaired children. British Journal of Ophthalmology, Vol. 89 (2): 2013-218, 2010.

11- KAMRAN A., BAKHTEYAR K., HEYDARI H., LOTFI A. and HEYDARIZ.: Survey of Oral Hygiene Behaviors, Knowledge and Attitude among School Children: A CrossSectional Study from Iran. International Journal of Health Sciences pp. 83-95. jhsnet.com/journals/ijhs/Vol_2_No_2, 2012.

12- BOULTON M., HAINES L., DIANE S. and FIELDER A.: Health Related Quality of Life of Children with Vision Impairment or Blindness, Development Medicine and Child Neurology, Cambridge Journals, Vol. 48 (8): pp. 656-661, 2006.

13- ELKHATEEB S. and ELHADEDI H.: Behavior and mental problems for people with vision important. http://wwwzulfi ed.gov, 2004.
14- KHUSNIA S.: Hubungan Dukungan Sosial Dan Kepercayaan Diri Pada Remaja Tunanetra di Panti Rehabilitasi Sosial Bina Cacat Netra Budi Mulya Malang. Surabaya: UIN Sunan Ampel. digilib. uinsby, 2010.

15- RAHAYU M. and SYAFAR M.: Personal Hygiene Concepts of Health Education for the Visually Impaired International Journal of Sciences. Basic and Applied Research (IJSBAR), 22 (1): 435-445. www.deuhy oedergi.org, 2015.

16- KHALAF M.A.H., EL-MOTAYAM, K. E. M., ABD ELGAWAD R.A. and OMARA A.A.: Oral Health Knowledge and Attitude of Caregivers and Oral Health Status of Children with Hearing Impairment. www.jofamericanscie nce.org, 2015.

17- ABD ELHAFZ S.M.: Nursing Assesment of Health needs for female adolescent students with blind. Faculty of nursing. Ain Shams in Cairo, 2013.

18- (UNESCO) United Nations Education, scientific and cultural organization: Challenges of implementing free primary education in Kenya experience From the district level. https://www.scribd.com/document, 2005.

19-PERCIVAL J. and HANSON J.: Visually impaired people's access to support, housing and independence. British journal of visual impairment, Vol. 25 (1): pp. 51-67. . pocklington-trust.org.uk, 2007.

20- VIRGINIA E.B.: Teaching visual impairment Children. 3 rd ed. Charles C. Thomas Publisher. USA. (https://books. google.com.eg/books? personal hygiene/blind children visual impairment, 2004.

21- ABD-EL SATTAR A.R. and MOHAMED ABD-EL AAL E.: Effect of Health Educational Program for Females BlindedAdolescents Students regarding Reproductive Health. Faculty of Nursing, Ain Shams University, Egypt American: Journal of Nursing Science, 2015.

22- KILLER A.: Public Health in New York City. Confronting Epidemics of the modern era international Journal of Epidemiology. 112-127. https://books.google.com , 2009.

23- MANE A.B., RADDY N.S., RADDY P., CHETANA K.V., et al.: Differences of Hand Hygiene and its Correlates among School going Children in Rural and Urban Area of Karnataka, India, Arch. Med., 8: 5. https://www. jpbms.info, 2016.

24- WILLAGEN J., JANSSEN N.H. and VERVLOED M.P.J.: Tactual profile: An assessment procedure for tactual functioning in children and adolescent. International Congress Series, 1282: 762-766, 2009.

25- KILLER A.: Public Health in New York City. Confronting Epidemics of the modern era international Journal of Epidemiology, 112-127. https://books.google.com , 2009.

26- MANE A.B., RADDY N.S., RADDY P., CHETANA K.V., et al.: Differences of Hand Hygiene and its Correlates among School going Children in Rural and Urban Area of Karnataka, India, Arch. Med., 8: 5. https://www.jpbms.info, 2016. 


\section{تقييم النظافة الشخصية لدى الطلبة ذو الإعاقة

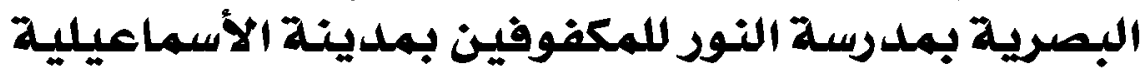

الإعاقة البصرية والعمى من أهم وأخطر المشكلات بالمجتمع. لما لها من تأثير طويل الأمد على الأطفال وأسرهم بالتالى لها تأثير على مهارات الرعاية الذاتية للطفل.

هدف الدراسة: تقييم النظافة الشخصية للطلبة ذوى الإعاقة البصرية بمدرسة النور المكفوفين بمدينة الأسماعيلية. عدد العينة: 1 طالب وطالبة و.7من مقدمى الرعاية للأطفال ذو الإعا قة البصرية. نوع الدراسة: دراسة وصفية.

أدوات جمع البيانات: تم جمع البيانات بواسطة الباحث عن طريق المقابلة الثخصية وذلك بإستخدام ثلاث أدوات لجمع البيانات: الأداة الأولى: عبارة عن أستمارة أستبيان تشمل البيانات الشخصية للطلبة المكفوفين وأسئلة لتقييم معلوماتهم العامة عن النظافة الشخصية.

الأداة الثانية: عبارة عن أستمارة ملاحظة لمهارات النظافة الشخصية.

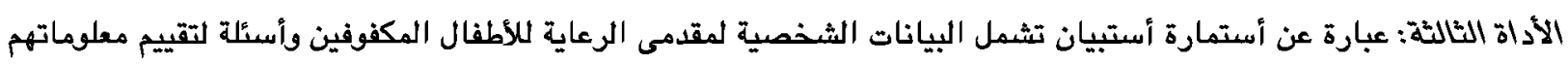
عن النظافة الشخصية لهوْلاء الأطفال.

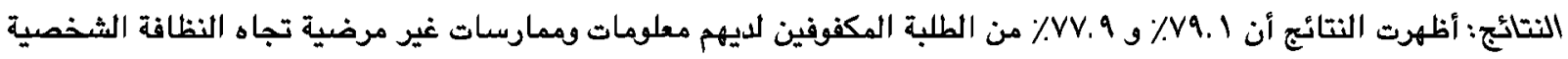
بينما 7 . I من مقدمى الرعاية لديهم معلومات مرضية عن النظافة الشخصية لأطفالهم بإستثناء نظافة الفم والأسنان. الأستتّاج من هذه الدراسة: الطلبة ذو الإعاقة البصرية لديهم معلومات وممارسات غير مرضية نحو النظافة الشخصية، وأن مقدمى بلفي الرعاية لديهم معلومات مرضية عن النظافة الشخصية لأطفالهم عدا العناية بالفم. التوصيات: التقييم المستمر لمعلومات وممارسات الطلبة ذو الإعاقة البصرية وأيضاً تقييم معلومات مقدم الرعاية وتزويدهم

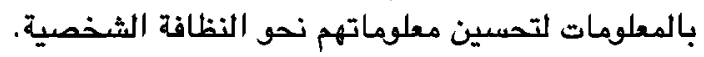

